\title{
The Influence of Marketing Management of Transportation Services on the Satisfaction of Public Services in Jakarta
}

\author{
Rahayu Kusumadewi, Agus Alamsyah Perwiranegara, Kustana \\ FISIP \\ UIN Sunan Gunung Djati Bandung \\ Bandung, Indonesia \\ rahayukusumadewi@yahoo.com
}

\begin{abstract}
The purpose of this study is to determine the effect of marketing management of transportation services to the satisfaction of public services in Jakarta. The research method used in this study is associative research method. It is a research that tries to find the relation of causality between one variable and another by using quantitative analysis techniques (statistics). To calculate the relationship and influence between the variables, the calculation of Rank Spearman Correlation Coefficient and Pearson Product Moment are used. The population of this study is the user community of online-based public transport services. The results of this study show that the variable of marketing management of transportation services significantly influence public satisfaction in Jakarta
\end{abstract}

Keywords - transportation; marketing management; public services.

\section{INTRODUCTION}

The important role of public transport services in economic development relates to the process of labor, the distribution of goods and services, and the core of economic movement. The current technological developments facilitate communication and interaction and even provide social change in society. Therefore, it can be said that communication technology is an application of science to solve the problems related to communication [1].

The rapid development of recent technology makes us possible to get the information and facilities easily and quickly. Such as by using the internet and various applications make us easier to get an online-based public transportation services that suits our needs. The presence of an online-based public transportation certainly triggered various reactions from the positive and negative community layers that relied on the conventional public transportation services. This is what lies behind the Permenhub no. 32 year 2016 on the implementation of people transport and public motor vehicles not in the route.

The presence of the Regulation of the Minister of Transportation no. 32 years 2016 on the implementation of people transport and public motor vehicles not in the trajectory affects the marketing management of transportation services in order to keep providing the satisfactory public services.
Maximum satisfaction of public servants will encourage loyalty so that people will continue to use the transportation services that affect the growth of the company. Consumer satisfaction is a major factor in the assessment of service quality. In this case, the consumers assess the service performance and feel directly the product of a service. The higher the perceived quality of service, the higher the level of customer satisfaction, and the more positive impact of one's intention to address the service [2].

Secretary General of the Ministry of Transportation, Sugihardjo, said that there are only $10 \%$ of public transportations based in Jakarta area who have registered and have an operational license. "From the data we get, for example: Grab Car application, managed by PT Solusi Transport Indonesia. There are 5,110 vehicles we identified. For DKI Jakarta area, there are only 347 vehicles that have been licensed. Thus, the 4,763 vehicles are unlicensed "said Sugihardjo in a press release [3]. He asserted, an application company that still provides online facilities to the public transport leases that do not have an operational license should be given sanctions. Therefore, he said, Kemenhub will provide input to the Ministers of Communications and Informatics who have an authority to make access termination or temporary blocking of the application provider. The existence of onlinebased transportation itself is much in demand by the society, although it causes a controversy among the existing transportation service providers.

\section{RESEARCH METHOD}

This research is a quantitative research which the data collection, the instrument used, and the analysis of the result involved the measures and figures of the statistical method. The approach of this study is descriptive verifikatif and using explanatory survey method. A descriptive approach is used to get an overview of the existing conditions of the marketing management of transportation services within the Jakarta network. A verifikatif approach is used to test the Marketing Management of Transport Service in Jakarta network and the influence of Marketing Management of Transportation Service on the Satisfaction of Public Service Transportation in Jakarta. 
The data collected in this study is a primary data that is a data obtained directly from the source, and a secondary data, which is obtained from the results of literacy studies. While the data collection techniques used are interviews, observations and questionnaires. The data analysis used in this study is a simple correlation analysis that is an analysis used to see a relation between two variables, correlation coefficient that shows closeness relation between the two variables [4].

\section{RESULT AND DISCUSSION}

\section{A. Research Instrumentation Test}

In the process of quantitative research, to produce a quality research, it is used a test to the results of the questionnaire to test the validity and reliability of the instrument.

TABLE I. TEST RESUlts OF DATA VALIDITY SERVICE MARKETING MANAGEMENT

\begin{tabular}{|l|l|l|l|l|}
\hline No & Instrument & r-count & r-table & \multicolumn{1}{|c|}{ Result } \\
\hline 1 & Instrument 1 & 0.521 & 0,300 & Significance \\
\hline 2 & Instrument 2 & 0.607 & 0,300 & Significance \\
\hline 3 & Instrument 3 & 0.661 & 0,300 & Significance \\
\hline 4 & Instrument 4 & 0.605 & 0,300 & Significance \\
\hline 5 & Instrument 5 & 0.610 & 0,300 & Significance \\
\hline 6 & Instrument 6 & 0.614 & 0,300 & Significance \\
\hline 7 & Instrument 7 & 0.470 & 0,300 & Significance \\
\hline 8 & Instrument 8 & 0.607 & 0,300 & Significance \\
\hline 9 & Instrument 9 & 0.480 & 0,300 & Significance \\
\hline 10 & Instrument 10 & 0.663 & 0,300 & Significance \\
\hline 11 & Instrument 11 & 0.627 & 0,300 & Significance \\
\hline 12 & Instrument 12 & 0.721 & 0,300 & Significance \\
\hline 13 & Instrument 13 & 0.466 & 0,300 & Significance \\
\hline 14 & Instrument 14 & 0.614 & 0,300 & Significance \\
\hline 15 & Instrument 15 & 0.498 & 0,300 & Significance \\
\hline 16 & Instrument 16 & 0.559 & 0,300 & Significance \\
\hline 17 & Instrument 17 & 0.687 & 0,300 & Significance \\
\hline
\end{tabular}

Based on the table I, it was obtained that the results of the value of r-count is entirely above 0.300 . The lowest validity value is found in the instrument 7 regarding the price charged in accordance with the service given with the r-count value of 0.470 , while the highest validity value is found in the instrument 17 concerning the creation of a safe and comfortable atmosphere during the journey with an r-count value of 0.687 . The conclusion is that the results of the validity test of the instrument for marketing service management variables entirely declared valid and can be further analyzed.

\section{B. Data Reliability Testing}

Data Reliability Testing is intended to determine the level of consistency and reliability of research variables data (Marketing Management Services) obtained from the perception of respondents in the questionnaires of the research distributed to the respondents.

TABLE II. RELIABILITY TESTING OF RESEARCH DATA

\begin{tabular}{|l|l|l|l|l|}
\hline No & \multicolumn{1}{|c|}{ Variable } & $\begin{array}{c}\text { alpha } \\
\text { cronbach }\end{array}$ & $\begin{array}{c}\text { comparative } \\
\text { value }\end{array}$ & Conclusion \\
\hline 1 & $\begin{array}{l}\text { Marketing } \\
\text { Management Services }\end{array}$ & 0,753 & 0,700 & Significant \\
\hline
\end{tabular}

Based on the table II, it was obtained that the value of alpha cronbach is above 0.700 which means that the reliability of the research variable data is reliable and can be further analyzed.

\section{Descriptive Analysis of Transportation Services Marketing Management Variables}

The result of the analysis which refers to the principles of service marketing that consisted of the 7P, namely: products, prices, places, promotions, people, processes, and physical facilities that can be seen in the description of the tables below.

TABLE III. VEHICLE COMPLETENESS PHYSICAL FACILITIES AND IN GOOD CONDITION

\begin{tabular}{|c|l|l|l|l|l|}
\hline \multicolumn{2}{|c|}{} & Frequency & Percent & $\begin{array}{c}\text { Valid } \\
\text { Percent }\end{array}$ & $\begin{array}{c}\text { Cumulative } \\
\text { Percent }\end{array}$ \\
\hline Valid & 1.00 & 1 & 0.5 & 0.5 & 0.5 \\
\cline { 2 - 6 } & 2.00 & 13 & 6.5 & 6.5 & 7.0 \\
\cline { 2 - 6 } & 3.00 & 39 & 19.5 & 19.5 & 26.5 \\
\cline { 2 - 6 } & 4.00 & 88 & 44.0 & 44.0 & 70.5 \\
\cline { 2 - 6 } & 5.00 & 59 & 29.5 & 29.5 & 100.0 \\
\cline { 2 - 6 } & Total & 200 & 100.0 & 100.0 & \\
\hline
\end{tabular}

Based on the table III, the result of the analysis shows that most of the respondents' perception, 88 respondents or $44.0 \%$, of both the vehicle physical completeness and vehicle condition of the online transportation service providers are good, and other respondents who stated very good are 59 respondents or $29.5 \%$, while those who perceive good enough are 39 respondents or $19.5 \%$. While opinions that are stated less good up to very less good in the assessment of the completeness of physical facilities and vehicle conditions of the online providers are 14 people or $7.0 \%$.

TABLE IV. Clothes APPEARANCE OF DRIVER (NEAT AND POLITE)

\begin{tabular}{|l|l|l|l|l|l|}
\hline \multicolumn{2}{|c|}{} & Frequency & Percent & $\begin{array}{c}\text { Valid } \\
\text { Percent }\end{array}$ & $\begin{array}{c}\text { Cumulative } \\
\text { Percent }\end{array}$ \\
\hline Valid & 1.00 & 2 & 1.0 & 1.0 & 1.0 \\
\cline { 2 - 6 } & 2.00 & 9 & 4.5 & 4.5 & 5.5 \\
\cline { 2 - 6 } & 3.00 & 43 & 21.5 & 21.5 & 27.0 \\
\cline { 2 - 6 } & 4.00 & 92 & 46.0 & 46.0 & 73.0 \\
\cline { 2 - 6 } & 5.00 & 54 & 27.0 & 27.0 & 100.0 \\
\cline { 2 - 6 } & Total & 200 & 100.0 & 100.0 & \\
\hline
\end{tabular}

Based on the table IV, the results of the analysis show that most of the respondents' perception of the drivers' clotting appearance of the online transportation service, as much as 92 respondents or $46.0 \%$, is good. They perceive that the drivers' appearances are polite and neat. Other respondents who state the drivers' appearances are very neat are 54 or $27.0 \%$, while the respondents who perceive neat enough are 43 respondents or $21.5 \%$. While the respondents that state less tidy up to very less neat in the assessment of the drivers' appearances are 11 people or $5.5 \%$.

TABLE V. INTERESTING ONLINE TRANSPORT BOOKING APPLICATION DESIGN

\begin{tabular}{|c|l|l|l|l|l|}
\hline \multicolumn{2}{|c|}{} & Frequency & Percent & $\begin{array}{c}\text { Valid } \\
\text { Percent }\end{array}$ & $\begin{array}{c}\text { Cumulative } \\
\text { Percent }\end{array}$ \\
\hline \multirow{3}{*}{ Valid } & 2.00 & 1 & 0.5 & 0.5 & 0.5 \\
\cline { 2 - 6 } & 3.00 & 16 & 8.0 & 8.0 & 8.5 \\
\cline { 2 - 6 } & 4.00 & 117 & 58.5 & 58.5 & 67.0 \\
\cline { 2 - 6 } & 5.00 & 66 & 33.0 & 33.0 & 100.0 \\
\cline { 2 - 6 } & Total & 200 & 100.0 & 100.0 & \\
\hline
\end{tabular}


Based on the table $\mathrm{V}$, the results of the analysis indicated that most of respondents perceive that the design of booking applications provided by online transport services is attractive, they are about 117 respondents or $58.5 \%$, and other respondents who said very interested as much as 66 or $33.0 \%$ while they who perceive interested enough as much as 16 respondents or $8.0 \%$. While the respondent that states less interest is 1 person or by $0.5 \%$.

TABLE VI. ONLINE TRANSPORTATION BOOKING APPLICATION (EASY TO UNDERSTAND AND USE)

\begin{tabular}{|l|l|l|l|l|l|}
\hline \multicolumn{2}{|c|}{} & Frequency & Percent & $\begin{array}{c}\text { Valid } \\
\text { Percent }\end{array}$ & $\begin{array}{c}\text { Cumulative } \\
\text { Percent }\end{array}$ \\
\hline \multirow{3}{*}{ Valid } & 2.00 & 4 & 2.0 & 2.0 & 2.0 \\
\cline { 2 - 6 } & 3.00 & 19 & 9.5 & 9.5 & 11.5 \\
\cline { 2 - 6 } & 4.00 & 93 & 46.5 & 46.5 & 58.0 \\
\cline { 2 - 6 } & 5.00 & 84 & 42.0 & 42.0 & 100.0 \\
\cline { 2 - 6 } & Total & 200 & 100.0 & 100.0 & \\
\hline
\end{tabular}

Based on the table VI, the results of the analysis show that most respondents perceive easy to understand the application of online transportation as much as 93 respondents or $46.5 \%$ and other respondents stated very easy as much as 84 or $42.0 \%$, while that perceives easy enough as much as 19 respondents or $9,5 \%$. While the respondents that state less understanding of the application online transportation services are 4 people or $2.0 \%$.

TABLE VII. CleAR SERVICE PRICE STANDARdS

\begin{tabular}{|c|l|l|l|l|l|}
\hline \multicolumn{2}{|c|}{} & Frequency & Percent & $\begin{array}{c}\text { Valid } \\
\text { Percent }\end{array}$ & $\begin{array}{c}\text { Cumulative } \\
\text { Percent }\end{array}$ \\
\hline \multirow{3}{*}{ Valid } & 2.00 & 2 & 1.0 & 1.0 & 1.0 \\
\cline { 2 - 6 } & 3.00 & 20 & 10.0 & 10.0 & 11.0 \\
\cline { 2 - 6 } & 4.00 & 97 & 48.5 & 48.5 & 59.5 \\
\cline { 2 - 6 } & 5.00 & 81 & 40.5 & 40.5 & 100.0 \\
\cline { 2 - 6 } & Total & 200 & 100.0 & 100.0 & \\
\hline
\end{tabular}

Based on the table VII, the result of the analysis shows that most of the respondents, 97 respondents or $48,5 \%$, perceive that the standard of service price of online transportation service is clear. 81 or $40,5 \%$ respondents state that it is very clear, while 20 respondents or $10.0 \%$ perceive clear enough. While the respondents that state unclear related to the price of services provided by the online transport are 2 people or by $1.0 \%$

TABLE VIII. INTERESTING AND COMPETITIVE OFFERED PRICE

\begin{tabular}{|c|l|l|l|l|l|}
\hline \multicolumn{2}{|c|}{} & Frequency & Percent & $\begin{array}{c}\text { Valid } \\
\text { Percent }\end{array}$ & $\begin{array}{c}\text { Cumulative } \\
\text { Percent }\end{array}$ \\
\hline \multirow{3}{*}{ Valid } & 2.00 & 3 & 1.5 & 1.5 & 1.5 \\
\cline { 2 - 6 } & 3.00 & 20 & 10.0 & 10.0 & 11.5 \\
\cline { 2 - 6 } & 4.00 & 108 & 54.0 & 54.0 & 65.5 \\
\cline { 2 - 6 } & 5.00 & 69 & 34.5 & 34.5 & 100.0 \\
\cline { 2 - 6 } & Total & 200 & 100.0 & 100.0 & \\
\hline
\end{tabular}

Based on the table VIII, the results of the analysis indicated that most of respondents, 108 respondents or $54,0 \%$, perceive that the standard price of services provided by online transportation services is attractive and competitive. 69 or
$34.5 \%$ respondents state that it is very interesting and competitive, while 20 respondents or $10.0 \%$ perceive attractive and competitive enough. While the respondents that state less attractive and competitive related to the price of services provided by online transportation are 3 people or $1.5 \%$.

TABLE IX. THE PRICE GIVEN IN ACCORDANCE WITH THE SERVICES PROVIDED

\begin{tabular}{|l|l|l|l|l|l|}
\hline \multicolumn{2}{|c|}{} & Frequency & Percent & $\begin{array}{c}\text { Valid } \\
\text { Percent }\end{array}$ & $\begin{array}{c}\text { Cumulative } \\
\text { Percent }\end{array}$ \\
\hline \multirow{3}{*}{ Valid } & 2.00 & 2 & 1.0 & 1.0 & 1.0 \\
\cline { 2 - 6 } & 3.00 & 30 & 15.0 & 15.0 & 16.0 \\
\cline { 2 - 6 } & 4.00 & 115 & 57.5 & 57.5 & 73.5 \\
\cline { 2 - 6 } & 5.00 & 53 & 26.5 & 26.5 & 100.0 \\
\cline { 2 - 6 } & Total & 200 & 100.0 & 100.0 & \\
\hline
\end{tabular}

Based on the table IX, the results of the analysis indicated that most of respondents, 115 respondents or $57,5 \%$, perceive that the standard price of services provided by online transportation services and the services provided is appropriate. 53 respondents or $26,5 \%$ state that it is very appropriate, while 20 respondents or $10.0 \%$ perceive appropriate enough. While the respondents that state less appropriate related to the price of services provided by online transportation and the services provided are 2 people or $1.0 \%$.

TABLE X. ClaRITY AND ACCURACY OF PICK UP TIME

\begin{tabular}{|l|l|l|l|l|l|}
\hline \multicolumn{2}{|c|}{} & Frequency & Percent & $\begin{array}{c}\text { Valid } \\
\text { Percent }\end{array}$ & $\begin{array}{c}\text { Cumulative } \\
\text { Percent }\end{array}$ \\
\hline Valid & 1.00 & 1 & 0.5 & 0.5 & 0.5 \\
\cline { 2 - 6 } & 2.00 & 11 & 5.5 & 5.5 & 6.0 \\
\cline { 2 - 6 } & 3.00 & 51 & 25.5 & 25.5 & 31.5 \\
\cline { 2 - 6 } & 4.00 & 81 & 40.5 & 40.5 & 72.0 \\
\cline { 2 - 6 } & 5.00 & 56 & 28.0 & 28.0 & 100.0 \\
\cline { 2 - 6 } & Total & 200 & 100.0 & 100.0 & \\
\hline
\end{tabular}

Based on the table $\mathrm{X}$, the result of the analysis shows that most of the respondents, 115 respondents or $57,5 \%$, perceive that the price given in accordance with the Services provided is appropriate. 53 or $26,5 \%$ respondents state that it is very appropriate, while 30 respondents or $15.0 \%$ perceive appropriate enough. While the respondents that state less appropriate between the prices with the services provided by online transportation are 2 people or $1.0 \%$.

TABLE XI. ClARITY AND ACCURACY OF TRAVEL TO DESTINATION

\begin{tabular}{|l|l|l|l|l|l|}
\hline \multicolumn{2}{|c|}{} & Frequency & Percent & $\begin{array}{c}\text { Valid } \\
\text { Percent }\end{array}$ & $\begin{array}{c}\text { Cumulative } \\
\text { Percent }\end{array}$ \\
\hline Valid & .00 & 1 & 0.5 & 0.5 & 0.5 \\
\cline { 2 - 6 } & 1.00 & 1 & 0.5 & 0.5 & 1.0 \\
\cline { 2 - 6 } & 2.00 & 16 & 8.0 & 8.0 & 9.0 \\
\cline { 2 - 6 } & 3.00 & 62 & 31.0 & 31.0 & 40.0 \\
\cline { 2 - 6 } & 4.00 & 73 & 36.5 & 36.5 & 76.5 \\
\cline { 2 - 6 } & 5.00 & 47 & 23.5 & 23.5 & 100.0 \\
\cline { 2 - 6 } & Total & 200 & 100.0 & 100.0 & \\
\hline
\end{tabular}

Based on the table XI, the result of the analysis shows that most of the respondents, 73 respondents or $36.5 \%$, perceive the travel time to the passenger destination of the online transportation service providers is clear and accurate. 47 
respondents or $23.5 \%$ state that it is very clear and accurate, while 62 respondent or $31.0 \%$ perceive accurate enough. While the respondent that states the travel time provided by the online transportation is less clear and accurate is 1 person or $0.5 \%$.

TABLE XII. DRIVERS' ADEQUATE DRIVING CAPABILITIES

\begin{tabular}{|c|l|l|l|l|l|}
\hline \multicolumn{2}{|c|}{} & Frequency & Percent & $\begin{array}{c}\text { Valid } \\
\text { Percent }\end{array}$ & $\begin{array}{c}\text { Cumulative } \\
\text { Percent }\end{array}$ \\
\hline \multirow{4}{*}{ Valid } & 2.00 & 6 & 3.0 & 3.0 & 3.0 \\
\cline { 2 - 6 } & 3.00 & 44 & 22.0 & 22.0 & 25.0 \\
\cline { 2 - 6 } & 4.00 & 97 & 48.5 & 48.5 & 73.5 \\
\cline { 2 - 6 } & 5.00 & 53 & 26.5 & 26.5 & 100.0 \\
\cline { 2 - 6 } & Total & 200 & 100.0 & 100.0 & \\
\hline
\end{tabular}

Based on the table XII, the result of the analysis shows that most of the respondents, 97 respondents or $48,5 \%$, perceive that the drivers of online transportation service have an adequate driving ability. 53 respondents or $26,5 \%$ state that the drivers are very capable, while 44 respondents or $22,0 \%$ perceive neutral. While the respondents that state the drivers of transport online are not capable are 6 people or $3.0 \%$.

TABLE XIII. FRIENDLY AND POLITE DRIVERS

\begin{tabular}{|l|l|l|l|l|l|}
\hline \multicolumn{2}{|c|}{} & Frequency & Percent & $\begin{array}{c}\text { Valid } \\
\text { Percent }\end{array}$ & $\begin{array}{c}\text { Cumulative } \\
\text { Percent }\end{array}$ \\
\hline Valid & 2.00 & 4 & 2.0 & 2.0 & 2.0 \\
\cline { 2 - 6 } & 3.00 & 52 & 26.0 & 26.0 & 28.0 \\
\cline { 2 - 6 } & 4.00 & 96 & 48.0 & 48.0 & 76.0 \\
\cline { 2 - 6 } & 5.00 & 48 & 24.0 & 24.0 & 100.0 \\
\cline { 2 - 6 } & Total & 200 & 100.0 & 100.0 & \\
\hline
\end{tabular}

Based on the table XIII, the result of the analysis shows that most of the respondents, 96 respondents or $48,0 \%$, perceive that the drivers of online transportation service are friendly and polite. 52 respondents or $26,0 \%$ state that the drivers are friendly and polite enough, while 48 respondents or $24,0 \%$ perceive very friendly and polite. While the respondents that state the drivers of transport online are not friendly and polite are 4 people or $2.0 \%$.

TABLE XIV. THE DRIVERS COMPLETED THEIR DUTIES PROPERLY

\begin{tabular}{|c|l|l|l|l|l|}
\hline \multicolumn{2}{|c|}{} & Frequency & Percent & $\begin{array}{c}\text { Valid } \\
\text { Percent }\end{array}$ & $\begin{array}{c}\text { Cumulative } \\
\text { Percent }\end{array}$ \\
\hline \multirow{3}{*}{ Valid } & 2.00 & 1 & 0.5 & 0.5 & 0.5 \\
\cline { 2 - 6 } & 3.00 & 36 & 18.0 & 18.0 & 18.5 \\
\cline { 2 - 6 } & 4.00 & 118 & 59.0 & 59.0 & 77.5 \\
\cline { 2 - 6 } & 5.00 & 45 & 22.5 & 22.5 & 100.0 \\
\cline { 2 - 6 } & Total & 200 & 100.0 & 100.0 & \\
\hline
\end{tabular}

Based on the table XIV, the result of the analysis shows that most of the respondents, 118 respondents or $59,0 \%$, perceive that the drivers of online transportation are good in completing their duties. 45 respondents or $22,5 \%$ state that the drivers are very good, while 36 respondents or $18,0 \%$ perceive good enough. While the respondent that states the drivers of transport online are not good in completing their duties is 1 people or $0,5 \%$.
TABle XV. CAll Center to Ask

\begin{tabular}{|c|l|l|l|l|l|}
\hline \multicolumn{2}{|c|}{} & Frequency & Percent & $\begin{array}{c}\text { Valid } \\
\text { Percent }\end{array}$ & $\begin{array}{c}\text { Cumulative } \\
\text { Percent }\end{array}$ \\
\hline Valid & 2.00 & 3 & 1.5 & 1.5 & 1.5 \\
\cline { 2 - 6 } & 3.00 & 22 & 11.0 & 11.0 & 12.5 \\
\cline { 2 - 6 } & 4.00 & 127 & 63.5 & 63.5 & 76.0 \\
\cline { 2 - 6 } & 5.00 & 48 & 24.0 & 24.0 & 100.0 \\
\cline { 2 - 6 } & Total & 200 & 100.0 & 100.0 & \\
\hline
\end{tabular}

Based on the table $\mathrm{XV}$, the result of the analysis shows that most of the respondents, 127 respondents or $63,5 \%$, perceive that call center facility owned by the provider of online transportation service is good. 48 respondents or $24,0 \%$ state that it is very good, while 22 respondents or $11,0 \%$ perceive good enough. While the respondents that state the call center facility is not good are 3 people or 1,5\%.

TABLE XVI. SERVICE KNOWLEDGE OG CALl CENTER OFFICERS

\begin{tabular}{|c|l|l|l|l|l|}
\hline \multicolumn{2}{|c|}{} & Frequency & Percent & $\begin{array}{c}\text { Valid } \\
\text { Percent }\end{array}$ & $\begin{array}{c}\text { Cumulative } \\
\text { Percent }\end{array}$ \\
\hline \multirow{3}{*}{ Valid } & 2.00 & 2 & 1.0 & 1.0 & 1.0 \\
\cline { 2 - 6 } & 3.00 & 48 & 24.0 & 24.0 & 25.0 \\
\cline { 2 - 6 } & 4.00 & 110 & 55.0 & 55.0 & 80.0 \\
\cline { 2 - 6 } & 5.00 & 40 & 20.0 & 20.0 & 100.0 \\
\cline { 2 - 6 } & Total & 200 & 100.0 & 100.0 & \\
\hline
\end{tabular}

Based on the table XVI, the result of the analysis shows that most of the respondents, 110 respondents or $55,0 \%$, perceive that call center officers in providing online services to customers is good. 48 respondents or $24,0 \%$ state that they are good enough, while 40 respondents or $20,0 \%$ perceive very good. While the respondents that state the call center officers are not good are 2 people or $1,0 \%$.

TABLE XVII. COMPETENCIES IN EXPLAINING SERVICES AND PROCESSES OF CALL CENTER OFFICERS

\begin{tabular}{|l|l|l|l|l|l|}
\hline \multicolumn{2}{|c|}{} & Frequency & Percent & $\begin{array}{c}\text { Valid } \\
\text { Percent }\end{array}$ & $\begin{array}{c}\text { Cumulative } \\
\text { Percent }\end{array}$ \\
\hline \multirow{3}{*}{ Valid } & 2.00 & 4 & 2.0 & 2.0 & 2.0 \\
\cline { 2 - 6 } & 3.00 & 46 & 23.0 & 23.0 & 25.0 \\
\cline { 2 - 6 } & 4.00 & 118 & 59.0 & 59.0 & 84.0 \\
\cline { 2 - 6 } & 5.00 & 32 & 16.0 & 16.0 & 100.0 \\
\cline { 2 - 6 } & Total & 200 & 100.0 & 100.0 & \\
\hline
\end{tabular}

Based on the table XVII, the result of the analysis shows that most of the respondents, 118 respondents or $59,0 \%$, perceive that the competencies of the call center officers in providing online services to customers is good. 46 respondents or $23,0 \%$ state that they are good enough, while 32 respondents or $16,0 \%$ perceive very good. While the respondents that state the competencies of the call center officers are not good are 4 people or $2,0 \%$.

TABLE XVIII. CALl CENTER OFFICERS RESPOND TO CONSUMER PROBLEMS

\begin{tabular}{|c|l|l|l|l|l|}
\hline \multicolumn{2}{|c|}{} & Frequency & Percent & $\begin{array}{c}\text { Valid } \\
\text { Percent }\end{array}$ & $\begin{array}{c}\text { Cumulative } \\
\text { Percent }\end{array}$ \\
\hline \multirow{6}{*}{ Valid } & 1.00 & 1 & 0.5 & 0.5 & 0.5 \\
\cline { 2 - 6 } & 2.00 & 5 & 2.5 & 2.5 & 3.0 \\
\cline { 2 - 6 } & 3.00 & 83 & 41.5 & 41.5 & 44.5 \\
\cline { 2 - 6 } & 4.00 & 77 & 38.5 & 38.5 & 83.0 \\
\cline { 2 - 6 } & 5.00 & 34 & 17.0 & 17.0 & 100.0 \\
\cline { 2 - 6 } & Total & 200 & 100.0 & 100.0 & \\
\hline
\end{tabular}


Based on the table XVIII, the result of the analysis shows that most of the respondents, 83 respondents or $41,0 \%$, perceive that the responsiveness of the call center officers to the problems experienced by consumers is good enough. 77 respondents or $38,5 \%$ state that they are good, while 34 respondents or $17,0 \%$ perceive very good. While the respondent that states the responsiveness of the call center officers to the problems experienced by consumers are not good is 1 people or $0,5 \%$.

TABLE XIX. CREATING A SAFE AND COMFORTY ATMOSPHERE DURING THE TRAVEL

\begin{tabular}{|c|l|l|l|l|l|}
\hline \multicolumn{2}{|c|}{} & Frequency & Percent & $\begin{array}{c}\text { Valid } \\
\text { Percent }\end{array}$ & $\begin{array}{c}\text { Cumulative } \\
\text { Percent }\end{array}$ \\
\hline Valid & 1.00 & 2 & 1.0 & 1.0 & 1.0 \\
\cline { 2 - 6 } & 2.00 & 6 & 3.0 & 3.0 & 4.0 \\
\cline { 2 - 6 } & 3.00 & 45 & 22.5 & 22.5 & 26.5 \\
\cline { 2 - 6 } & 4.00 & 85 & 42.5 & 42.5 & 69.0 \\
\cline { 2 - 6 } & 5.00 & 62 & 31.0 & 31.0 & 100.0 \\
\cline { 2 - 6 } & Total & 200 & 100.0 & 100.0 & \\
\hline
\end{tabular}

Based on the table XIX, the result of the analysis shows that most of the respondents, 85 respondents or $42,5 \%$, perceive that the provider of online transportation service is able to create a safe and comfortable atmosphere during the travel. 62 respondents or $31,0 \%$ state that it is very good, while 45 respondents or $22,5 \%$ perceive good enough. While the respondents that state the provider of online transportation service is able to create a safe and comfortable atmosphere during the travel are 2 people or $1,0 \%$.

\section{Verifikatif Analysis}

The Influence of Application of Transportation Service Marketing Management on the Satisfaction of Public Service in Jakarta

Analysis of the influence of marketing management of transportation services on the satisfaction of public services is intended to know the level of influence of marketing management of transportation services on the Satisfaction of Public Service through linear regression analysis.

\section{1) Regression Coefficient Analysis}

TABLE XX. REGRESSION COEFFICIENT OF THE VARIABLE OF MARKETING MANAGEMENT OF TRANSPORTATION SERVICE ON THE SATISFACTION OF PUBLIC SERVICE

\begin{tabular}{|c|c|c|c|c|c|c|}
\hline \multirow{2}{*}{\multicolumn{2}{|c|}{ Model }} & \multicolumn{2}{|c|}{$\begin{array}{c}\text { Unstandardized } \\
\text { Coefficients }\end{array}$} & \multirow{2}{*}{$\begin{array}{c}\begin{array}{c}\text { Standardized } \\
\text { Coefficients }\end{array} \\
\text { Beta } \\
\end{array}$} & \multirow[b]{2}{*}{$\mathbf{t}$} & \multirow[b]{2}{*}{ Sig. } \\
\hline & & B & Std.Error & & & \\
\hline 1 & $\begin{array}{l}\text { (constant) } \\
\text { VAR_Y }\end{array}$ & $\begin{array}{l}13.033 \\
0.653\end{array}$ & $\begin{array}{l}2.960 \\
0.043\end{array}$ & 0.733 & $\begin{array}{l}4.404 \\
15.141\end{array}$ & $\begin{array}{l}0.000 \\
0.000\end{array}$ \\
\hline
\end{tabular}

Based on the table XX the price of 13,033 represents a constant value (a) which indicates that if there is no increase in marketing management of transportation services, then the satisfaction of public service will reach 13,033. The price of 0.653 is a regression coefficient which indicates that in every one addition point of marketing management of transportation service, there will be an increase in public service satisfaction of 0.653 .

\section{2) Correlation Analysis}

TABLE XXI. CORRELATION COEFFICIENT

\begin{tabular}{|l|c|l|l|l|}
\hline Model & R & R Square & $\begin{array}{c}\text { Adjusted R } \\
\text { Square }\end{array}$ & $\begin{array}{c}\text { Std. Error of } \\
\text { the Estimate }\end{array}$ \\
\hline 1 & $0.733^{\mathrm{a}}$ & 0.537 & 0.534 & 4.82860 \\
\hline
\end{tabular}

Based on the table XXI, it can be seen that the correlation coefficient between independent and dependent variable is 0.537. Correlation coefficient that marked positive means correlation that happened between marketing service management variable with satisfaction of public services unidirectional, in which the higher independent variable, the higher the dependent variable. The value of 0.004 shows the correlation between independent variables (service marketing management) and the dependent variable (satisfaction of public service) is in the category of strong relation $(0,400-0,599)$.

\section{3) Hypothesis testing}

TABLE XXII. HYPOTHETICAL TEST OF MARKETING SERVICE MANAGEMENT ON Public SERVICE SATISFACTION

\begin{tabular}{|cc|c|l|l|l|c|}
\hline \multirow{2}{*}{ Model } & \multicolumn{2}{|c|}{$\begin{array}{c}\text { Unstandardized } \\
\text { Coefficients }\end{array}$} & $\begin{array}{c}\text { Standardized } \\
\text { Coefficients }\end{array}$ & \multicolumn{1}{c|}{ t } & Sig. \\
\cline { 3 - 7 } & \multicolumn{1}{|c}{$\boldsymbol{B}$} & Std.Error & \multicolumn{1}{c|}{ Beta } & & \\
\hline 1 & (constant) & 13.033 & 2.960 & 0.733 & 4.404 & 0.000 \\
& VAR_Y & 0.653 & 0.043 & & 15.141 & 0.000 \\
\hline
\end{tabular}

Based on the table XXII, we can see that the value of ttable obtained by each variable. To make a conclusion accept or reject Ho, it must first be determined t-table values to be used. This value depends on the value of degree of freeedom (df) and the level of significance used. Using a 5\% significance level and a df value of $\mathrm{n}-\mathrm{k}-1(200-1-1=198)$, it is obtained a t-table value of 1.972. Based on the output, it is known that the value of t-count is 15.141 . When compared with the t-table value of 1.972 then the t-count obtained is much greater than the value of t-table. So Ho is rejected. Thus it can be concluded that the variable of service marketing management implementation significantly influences the satisfaction of public services.

\section{CONCLUSION}

The service marketing management has been well implemented by the providers of online transportation service in Jakarta. The highest assessment is on the design indicator of online transport booking application, clear price standards and call center to ask. As for the lowest assessment is the vehicle's physical facilities, the appearance of driver's clothing and capabilities. Users of online transportation services generally have sufficient satisfaction from online transport service providers. The highest assessments are in the presence of rapid response, security in transacting services on online transport services, feedback and rating from consumers on service and motivation to the public to continually improve their use. While the lowest value of public service satisfaction is in the flexible aspect to find alternative ways to avoid congestion on the road, so this becomes the cause of public satisfaction a little disturbed. 


\section{REFERENCES}

[1] Anindhita, W. A. ANALISIS PENERAPAN TEKNOLOGI KOMUNIKASI TEPAT GUNA PADA BISNIS TRANSPORTASI OJEK ONLINE (Studi pada Bisnis Gojek dan Grab Bike dalam Penggunaan Teknologi Komuniasi Tepat Guna untuk Mengembangkan Bisnis Transportasi). [In Prosiding Seminar, November 2 2016]
[2] Sukmawati, K. "Pengaruh Kualitas Layanan, Harga, dan Kepuasan Pelanggan terhadap Loyalitas Pelanggan Jasa Transportasi Kereta Api Eksekutif'. 2012.

[3] Supriyanto, Y. "Perusahaan Aplikasi Penyedia Jasa Transportasi Diminta Patuhi Peraturan". Retrieved from Industri Bisnis: http://industri.bisnis.com/read/20170313/98/636630/javascript 2017.

[4] Runtuwene, F. "Pengaruh Motivasi Kerja Terhadap Kinerja Pegawai di Badan Kepegawaian Daerah Kabupaten Minahasa Selatan". Jurnal Eksekutif, 7-8 2015. 